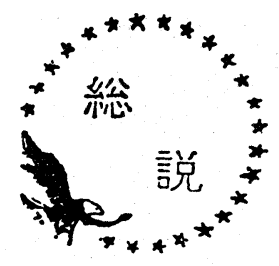

重油燃焼における炭素質の生成
は じめに

重油燃焼についての工学的研究は国内ではあまり多 くない。重油がわが国のエネルギーの主要部分を占め ていることを考えると奇異の感がする。これは重油然 焼という現象が複雑であり，しかも価格が低いという ことも一因であろう。重油燃焼に伴う炭素質生成につ いての講演を依頼されたが，何分にもこの分野での研 究が少なく, その対策を明確に打出すことは困難な現 状であり，やむをえずこの分野に関して筆者らが研究 してきた数少ない報告を基にしてお話し申し上げる点 を免じて頂きたい。

\section{1. 炭化水素燃料の燃焼に伴つて発生する岸素質}

重油をはじめ, 炭化水素然料は, 燃焼に伴つて炭素 質を発生する。そして, 通常, 炭素とかカーボンなど といつている燃焼生成物を元素分析すると水素が 1 〜 $3 \%$ 程度含まれている。これは, 重量百分率であ つて, 原子数百分率では水素が $12 \sim 36 \%$ 程度にな る。すなわち，炭素原子のみから構成されているので はなく，黒鉛に似た結晶構造をもつ有機化合物であ る。このような炭素に近い有機化合物は, 普通, 炭素 質 (Carbonaceous Substance) とよばれる。

燃燒によつて発生した炭素質の生成の履歴を調べる と, たとえていえば, 成人後の性格 (結晶の構造) に たいして生まれ（炭化水素の種類）よりもその生い立 ち (生成過程) が大きく関係していて興味深い。つま り,氏（うじ）ょり生い立ちということである。以下 にそれぞれの生い立ち別に考察し, 重油から発生した 実用機関の炭素質について考えてみる。

\section{2. 炭素質の生成過程と分類 ${ }^{1}$}

炭化水素然料が然焼するさいに発生する炭素質はそ の過程や外観から種々の名称で呼ばれている。ここで は大谷 ${ }^{2} の$ 分類にしたがつて, その生成過程から気相 析出型, 残留炭素型, 固気界面析出型の 3 種に分類し て考えよう。

\section{2-1 炭素質の分類}

（1）気相析出型炭素質

蒸発あるいは，ガス化（熱分解による）した炭化水
素然料から発生する炭素質で, 一般にスート (Soot) とよばれているものがこれに相当する。いわゆるラン プ・ブラックである。

数 $10 \AA$ 数 $100 \AA$ 程度の粒子でその生成過程は, Thomas $^{3)}$ の提案が妥当とみられている。(図 1 参照) 発生条件などは秋田 ${ }^{4)}$ の総説を参照されたい。

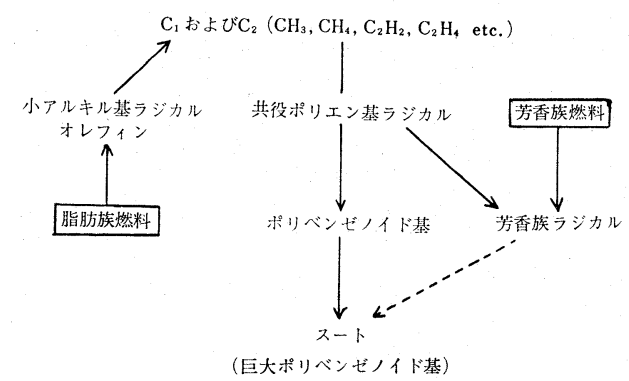

図 1 スート生成の過程図

A. Thomas, Comb. \& Flame, 6, 1, 46 (1962) に よる。破線は大谷 ${ }^{2}$ が付け加えることを提案した。

(2) 残留炭素

Residual Carbon あるいは, Coke とよばれる炭素 質で, 重質炭化水素が加熱されると熱分解によつて大 分子が切れていくと同時に, 発生したラジカル同志の 重合あるいは縮合反応が進行し，炭素質化が進む。こ の結果，残留する炭素質である ${ }^{5)}$ 。

重油の液滴を燃焼させるとセノスファー, コーク,ケ ージ，マトリクスなど各種の名称でよばれている炭素 質が残ることは，多くの研究者によつて報告されてい る $^{(6)}$ 。この炭素質も残留炭素とよばれるものである。

(3) 固気界面析出炭素質

気相の炭化水素が比較的高温で然焼するとき（たと えば,アセチレンー酸素炎切断器で酸素をやや少なくす ると輝いた炎が発生する)ノズル先端(固一気界面)に美 麗な王冠状の炭素質結晶が生長していく。このような 炭素質をクラウン ${ }^{13)}$ 名づけている。のように生成 過程で発生する炭素質を固気界面析出炭素質とよぶ。

2-2 重油燃焼で発生した炭素質の外観

もっぱら重油を噴霧燃焼している水管式ボイラの煙 
突下部や煙道に多量の炭素質が堆積することがよく知 られている。図2 はある工場の煙突下部で採集した岑

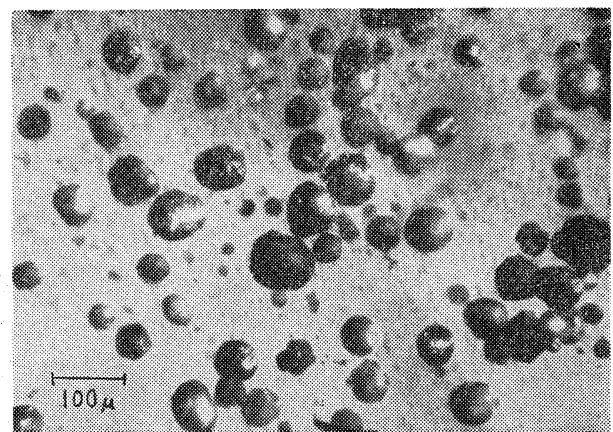

図 2 水管式ボイラー煙道下部に堆積した炭素質 粒子 (残留炭素粒子)

素質の顕微鏡写真である。図にみるように炭素質粒子 は数 10 100 $\mu$ 程度の粓径範囲の，表面にガス噴出痕 らしき凸凹をもつ小球で，いわゆるコークとよばれる 残留炭素粒子らしいことが推察される。

実用炉では比較的高温度で，すなわちよい燃焼状況 で重油噴霧を燃焼させ，なおかつこのような堆積物が 発生するのであるが，もつと悪い条件ではどうか？ 実験炉を用いて，比較的粗い噴霧（体面積平均粒径約 $100 \mu$ 以上）を低い空気率（ $m=1.1$ 以下）で然燒さ せると多量のばい煙が発生する。この煙道ガスを吸引 捕集して顕微鏡写真を撮つたのが図 3 である。

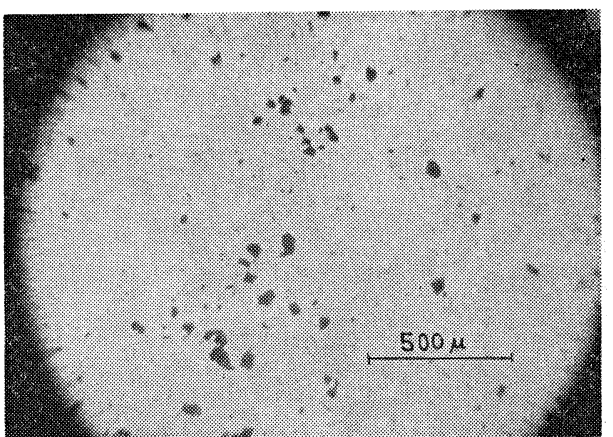

図 3 実験炉で発生したばい煙の顕微鏡写真（残 留炭素粒子とスートとの共存を示す)

図 3 をみると数 $100 \mu$ 程度の粒径をもつ粒子がみ られ，比較的大粒子と無数の微小粒子とから構成され ていることが認められる。この数ミクロンのオーダー の微小粒子に着目して電子顕微鏡写真を撮影すると図 4 のごとくで, この粒子は数 $10 \AA$ 程度の 1 次粒子が集 まつてできている微小粒子（数 $100 \AA ̊$ 数ミクロン程 度の 2 次あるいは 3 次粒子）であることがわかる。こ

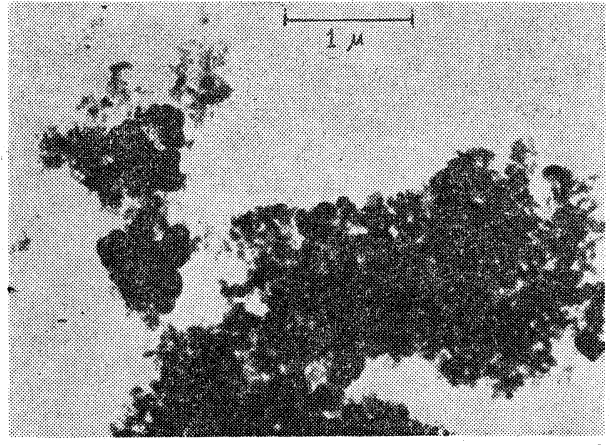

図 4 実験炉で発生したスートの電子顕微鏡写真

の粒径の大きさから判断すると比較的大粒子のグルー プは残留炭素粒子であり, 微小粒子は気相析出炭素質 のスート粒子であろうと推定される。

霧化の良好な重油液滴群の燃燒の場合には，実験的 に気相析出炭素質のスートはほとんど炉端では, 捕集 されなかつた。

\section{2-3 炭素質のX線回折による検討}

前述の 3 種類の生成過程によつて各種の炭化水素燃

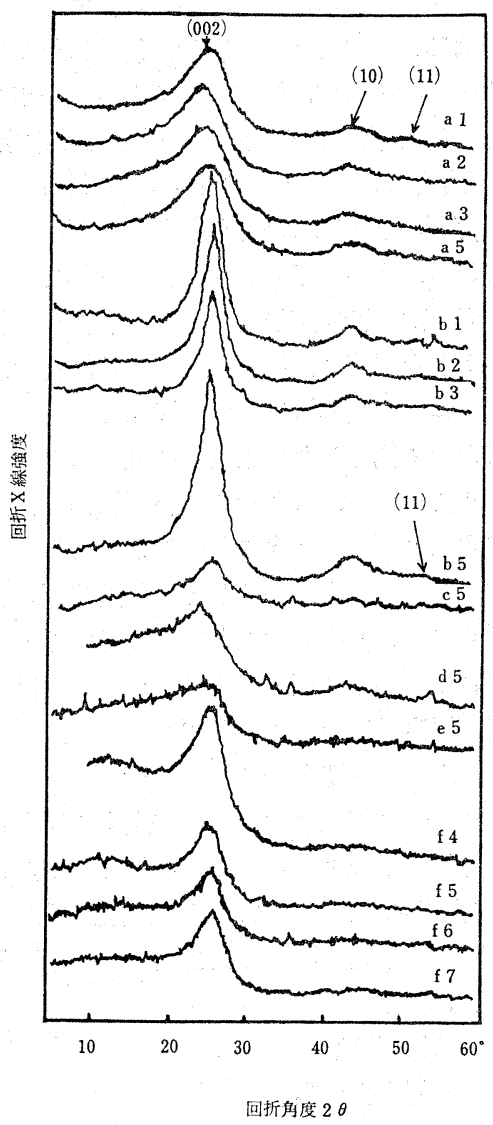

図 5 各種炭素質のX線回折図 
表 1 炭化水素燃料から生成された炭素質の結晶構造

生成過程、炭素質の宸化水素燃図 5 の ( 002$)$ (10)

\begin{tabular}{|c|c|c|c|c|c|c|c|c|c|}
\hline 生成過程 & $\begin{array}{l}\text { 炭素質の } \\
\text { 名 称 }\end{array}$ & $\begin{array}{l}\text { 崖化水素燃 } \\
\text { 料 の 種 類 }\end{array}$ & $\begin{array}{l}\text { 図 } 5 \text { の } \\
\text { 符 号 }\end{array}$ & $d[\AA]$ & $\begin{array}{l}02) \\
L_{c}[\AA]\end{array}$ & $d[\AA]$ & 10) $\operatorname{La}_{a}[\AA]$ & $\begin{array}{l}(11) \\
d[\AA]\end{array}$ & $\begin{array}{l}\text { 7A banc } \\
d[\AA]\end{array}$ \\
\hline \multirow{4}{*}{ 気相より析出 } & \multirow{4}{*}{$\begin{array}{c}(\text { スート) } \\
\left(\begin{array}{l}\text { ランプ・・ } \\
\text { ブラック }\end{array}\right)\end{array}$} & $(i$ オオクタン & $a-1$ & 3.58 & 11.9 & 2.08 & 41.6 & ナシ & ナシ \\
\hline & & $n-セ$ タン & $a-2$ & 3.75 & 9.2 & 2. 10 & 41.6 & ナシ & ナシ \\
\hline & & $\left\{\begin{array}{l}\alpha \text { チチル } \\
\text { ナフタレン }\end{array}\right.$ & $a-3$ & 3. 62 & 8.9 & 2. 08 & 46.2 & ナシ & ナシ \\
\hline & & (B 重 油 & $a-5$ & 3.59 & 10.8 & 2.08 & 39.9 & ナシ & ナシ \\
\hline \multirow{4}{*}{ 固気界面析出 } & \multirow{4}{*}{$\begin{array}{l}\text { カーボン・ } \\
\text { クラウン }\end{array}$} & \multirow{2}{*}{$\left(\begin{array}{l}\text { イソォクタ } \\
\text { ン }\end{array}\right.$} & $b-1$ & 3.49 & 23. 1 & 2.08 & 48.5 & $\begin{array}{l}1.74 \\
\text { 僅加 }\end{array}$ & 8.2 \\
\hline & & & $b-2$ & 3.47 & 27.1 & 2.09 & 48.5 & 1.74 & $\begin{array}{l}6.7 \\
\text { 僅品 }\end{array}$ \\
\hline & & $\begin{array}{l}\alpha \text { ヂチル } \\
\text { ナフダレン }\end{array}$ & $b-3$ & 3.47 & 29.1 & 2.08 & 67.2 & $\begin{array}{l}1.74 \\
\text { 僅加 }\end{array}$ & 7.9 \\
\hline & & B 重 油 & $b-5$ & 3.52 & 23.2 & 2.07 & 40.6 & $\begin{array}{l}1.72 \\
\text { 広 }\end{array}$ & 痕跡 \\
\hline \multirow{7}{*}{$\begin{array}{l}\text { 液相より反応 } \\
\text { とょり固相へ }\end{array}$} & $\begin{array}{l}\text { 煙道カーボ } \\
\text { ン(コーク) }\end{array}$ & B 重 油 & $c-5$ & 3.55 & 23.2 & 2.11 & 51.4 & ナシ & 7.25 \\
\hline & $\begin{array}{l}\text { カーボン・ } \\
\text { フラワー }\end{array}$ & B 重，油 & $\mathrm{d}-5$ & 3.69 & 9.8 & 2.12 & 28.6 & ナシ & $\begin{array}{l}\text { 痕跡 } \\
6.5\end{array}$ \\
\hline & \multirow[t]{2}{*}{ 表面皮膜 } & 重 油 & $e-5$ & 3.56 & 15.2 & 2.12 & 26.0 & ナシ & 嚾汃 \\
\hline & & A 重 油 & $f-4$ & 3.53 & 17.2 & 2.11 & 35.0 & ナシ & 7.6 \\
\hline & \multirow{3}{*}{$\begin{array}{l}\text { コンラドソ } \\
\text { ン残留炭素 }\end{array}$} & B 重 油 & $f-5$ & 3.56 & 17.6 & 2.12 & 29.5 & ナシ & 7.7 \\
\hline & & $\mathrm{C}$ 重 油 & $f-6$ & 3.48 & 16.5 & 2.07 & 36.5 & ナシ & 6.6 \\
\hline & & 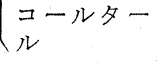 & $f-7$ & 3.45 & 17.7 & 2.06 & 49.7 & ナシ & 7.0 \\
\hline
\end{tabular}

料からえられた炭素質, および実用炉の堆積物とディ 一ゼルノズル先端に発生したカーボンフラワーをX線 回折を用いて検討した。その測定曲線を図 5 に解析結 果を表 1 亿示した ${ }^{1)}$ 。

いずれの炭素質も炭素特有の (002)および (10) のバンドが明らかにみとめられる。しかし表 1 に みられるよらに生成過程による結晶構造の差異は みとめられない。すなわち, 従来加ら用いられて いる結晶回折法は生成過程の判別に対し，このか ぎりでは採用できないことになる。

筆者らはこの判別手段を探求した結果, 新しい事実 に気付いた。すなわち図 5 亿おいて，従来炭素質特有 とされている(002)や(10) の山のほかに, $12^{\circ}(2 \theta)$ の部分にわずかではあるが残留炭素質やクラウンには 山がみとめられ，スートにはみとめられないことに気 付いた。そしてこの部分の山は, 約 $7 \AA$ の山に相当す るので, $7 \AA$ バンドとよぶことにする。この $7 \AA$ バン ドの意味するところは目下不明である。図 5 は不明確 であるので， $7 \AA$ バンドの細部について $\mathrm{B}$ 重油から 3 種類の生成過程でえた炭素質を定時計数法を用いて 解析を行なつたのが図 6 である。図 6 をみると同一B 重油から 3 種類の生成過程によつて, $7 \AA$ バンドが出 現したり，しなかつたりすることがよくわかる。つま

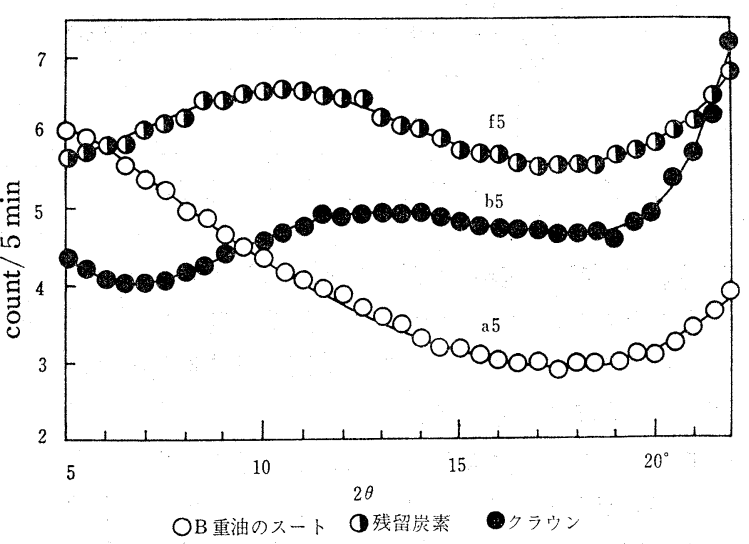

図 $6 \mathrm{X}$ 線定時計数法回折図

りX線回折によつて $7 \AA$ バンドがみとめられる炭素 質は残留炭素か固気界面析出炭素質であり, ない場合 は気相析出炭素質であるとみることができる。

一方, 前節で述べたとおりそれぞれの炭素質は生成 過程によつてその外観が異なるので，X線回折と外観 検査とを併用すれば，その炭素質の生成過程がいずれ かを判定することができる。

重油噴霧燃燒によつて煙道や煙突下部に堆積した炭 素質は表1に示したよ与炡残留炭素とみてよい。 


\section{3. 重油噴霧燃焼におけるカーボン発生の 定性的考察}

以上で，炭素質の生成過程の差異により炭素質の外 観やX線回折に相異点があり, 生成過程の判別ができ ることを述べた。そして，重油の噴霧燃焼に際して発 生する炭素質は大別して残留炭素粒子と気相析出炭素 質であるスート粒子とがあることを述べた。いうまで もなくスート粒子は，重油燃焼によつて熱をとりだす ときに大きな役割を果たす輝炎放射の原因となるもの である。

重油液滴の燃焼速度は約 $1,000^{\circ} \mathrm{C} て ゙ ~ 1 \mathrm{~mm}^{2} / \mathrm{sec}$ 程 度であるのにたいし，炭素質の燃焼速度は $0.03 \mathrm{~mm}^{2}$ /sec 程度であつて*, 燃焼雾囲気中の酸素がすでに大 部分消費しつくされてしまつた状況では炭素質の燃焼 速度はさらに低くなる。1 個の重油液滴の燃焼過程を 考えると，まず蒸発，ガス化燃焼が完了し，つづいて

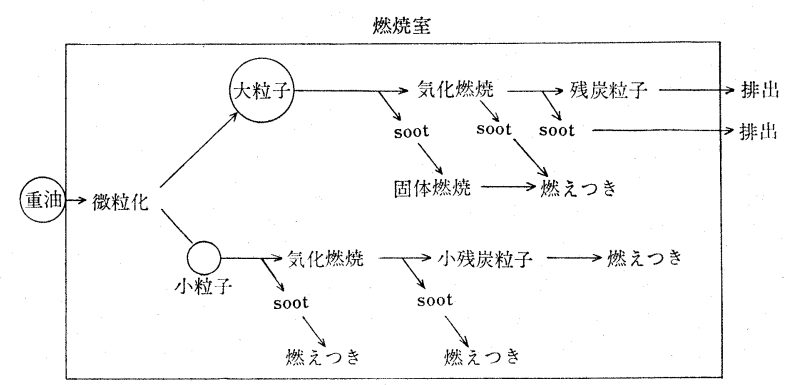

図 7 重油噴霧燃焼における炭素質発生のプロセス

固体然焼（残留炭素の）が起こり, 次第に粒子は燃え つきるとみられる。したがつて，燃焼速度から考える と, 所要然えつき時間の大部分は固体燃焼期間によつ て占められることになる。

重油の噴霧燃焼では同時にスート粒子の発生も考慮 する必要がある。すなわち，スート粒子と残留炭素粒 子とは図 7 に図式化したような経過をへて燃えつきた り，排出されたりするものと考えることができよう。 図 7 のように考えると比較的大粒径の液滴から大きな 残留炭素粒子が発生し，かつ残留炭素化が完了せず, ガス化燃焼が燃焼するような場合は燃焼室の末端近く

* 炭素質の嵩密度 $1 \mathrm{~g} / \mathrm{cm}^{3}, 1$ 気圧で空気は充分にあ るとし, Essenhigh ${ }^{14)}$ の式によつて計算した值。スー ト粒子はオングストロームのオーダーで, ミクロンの オーダーの残留炭素粒子とそれぞれの燃えきり時間と を比較すれば, 残留炭素粒子は $10^{4} \sim 10^{6}$ 倍の時間 が かかることになる。酸素分圧が変化してもおのおの同 一の分圧ではこの比率は変わらない。
でもスートの発生が続くと考えられる。したがつて, 大粒径の液滴を含む粗い重油噴霧の燃焼に際しては図 3 に示したようにスートと残留炭素粒子とが混合して 排出されるとみることができよう。

このように，重油噴霧燃焼における炭素質発生の因 子として，化学的な燃焼諸条件とともに物理的な燃焼 条件である重油液滴群の粒度分布が重要であることが 指摘される。

\section{4. ノズル先端に生成するカーボン・フラワー}

重油の噴霧燃焼を行なうディーゼル機関の噴射弁や 窯炉用のバーナーのノズル先端にカーボン・フラワー とよばれる嘴形の炭素質の発生をみることがしばしば ある。この種の炭素質の生因についての考察は筆者の 寡聞か，ほとんどみあたらない。

筆者らがX線回折によつてカーボン・フラワーを調 ベたところ $7 \AA$ バンドの存在がみとめられ，その生 成過程は 残留炭素であるとみられる。（表 1 参照)

目下，筆者らむさらにこの生成原因の詳細 は研究継続中であつて明確ではないが，図 8 のようなプロセスを経て残留炭素が生成され るものとみている。

すなわち，なんらかの理由でノズル先端部 が重油で濡れ，その重油膜は熱をうけてガス 化と残留炭素化が進行し，そのくりかえし (ディーゼルの場合) あるいは継続（バーナ 一の場合)によつて残留炭素は累積されてい く。その際, 流体力学的な問題, 熱の移動速 度と炭素質の生成速度および然焼速度との関連など, 複雑な形式で進行するものであろらと推定している。

よく知られているように，カーボン・フラワーの発 生は重油の微粒化を悪化させ, ひいては燃焼状態を悪 化させる。生成原因として, 上述の推論が認められる ならば，その生成防止策として

i ）ノズル先端の濡れの防止 $\rightarrow$ 機構的, 材料的, 流 体力学的な方策

ii）濡れた重油膜の炭化の防止 $\rightarrow$ 油膜が炭化反応を 起こさないよう十分低い温度にまで泠却してやる29), 濡れた油を速かに除去するなど。

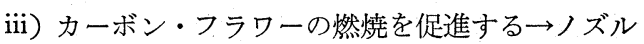
先端の炭素質が燃焼するに十分なよう高温度に保つ， 適当な燃焼促進剂を添加する，ノズル先端部にたいす る酸素の乱流拡散の改善など。

ここで，ii)，iii）において与えるべきノズル先端の 温度条件が相反しているが，いずれの方法も防止に対 


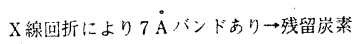

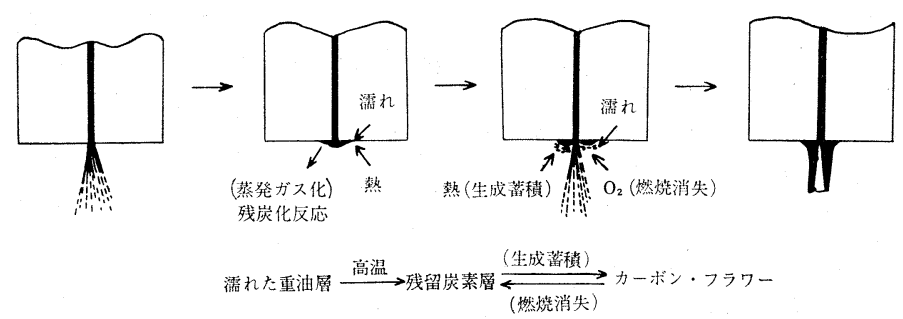

図 8 ノズル先端に発生するカーボンフラワーの発生機構の推定

して有効であろう。

以上の対策は, その生成原因の詳細が不明である現 状からして，あくまでも推論の域を脱しないことをお 断わりする。

\section{5. 炭素質の燃焼速}

度前述の諸点から, 重油の噴霧燃焼においては炭素 質の燃焼速度がカーボン発生と大きく関係することが 理解される。そして, 炭素質の燃焼については従来か ら多くの研究者によつて研究されてきた ${ }^{14) 24) 。}$

しかし，多くの知識も蓄えられたが，いまだに不明 の点も少なくない。以下にこれらの研究を簡単に紹介 しよう。

炭素質の燃焼についての従来の学説を大きく分類す ると表 2 のごとくになる。炭素質の燃焼反応速度は比

\section{表 2 炭素質燃焼の律速}

\begin{tabular}{clc} 
温度範囲 & \multicolumn{1}{c}{ 律 速 } & 反応の次数 \\
$500 \sim 800^{\circ} \mathrm{C}$ & 吸着, 化学反応 & 1 次 \\
$800 \sim 1,200^{\circ} \mathrm{C}$ & 境膜拡散 & 凝 1 次 \\
$1,200 \sim$ & 脱離 高温化学反応 & 0 次
\end{tabular}

較的低温では化学反応速度がそのまま燃焼速度になる が， $1,000^{\circ} \mathrm{C}$ 前後では炭素質表面のガス境膜を通つて 酸素が拡散してくる速度が律速*になるといら考えが 多く採用されている。さらに，炭素粒子内部の細孔内 拡散が律速であるとの学説もある22 ${ }_{23)}$ 。これらの考え 方を総括して拡散律速ということができよう。

さらに高温の場合，表 2 にみるように炭素質表面で の反応生成物の脱離が律速となる。化学反応律速と拡 散律速では酸素分圧の 1 乗に比例するが, 高温での脱

*律速とは rate control の訳語で, 化学に打ける 術語であつた。現在では物理的, 化学的に速度をきめ ることから，いくつかの事象が連続しておこるとき， その事象のうち, 最も遅いものが速度を定めるといら 意味でつかわれることが多い。
離律速（高温化学反応律速ともいら）では酸素分圧の 0 乗, すなわち高温では酸素分圧に無関係となり温度 のみの関数となる。詳細については Essenhigh ${ }^{14)} や$ 功刀 ${ }^{18)}$ の展望あるいは文献を参照していただきたい。 著者ら ${ }^{21)}$ も残留炭素の燃焼速度を $400^{\circ} \mathrm{C} \sim 800^{\circ} \mathrm{C}$ の 範囲で実験的にもとめその活性化エネルギー $40 \mathrm{kcal}$ /mole をえたが, この值は従来の文献值とほぼ一致 している。

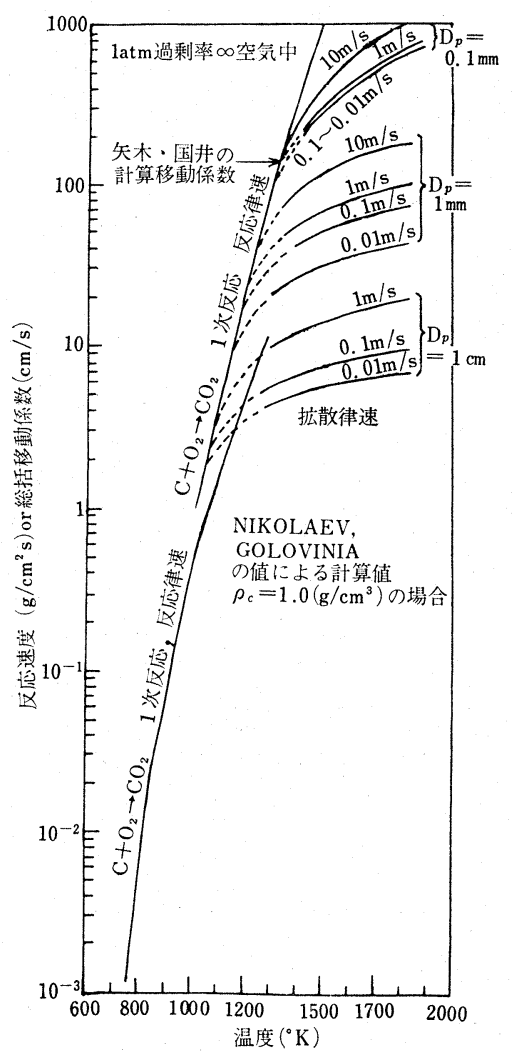

図 9 炭素の燃焼速度と温度との関係

(低温化学反応律速と抬散律速との共存) 
以上，温度によつて炭素質の燃燒速度がどう変わる かについて述べた。

つぎに，炭素質粒子の大きさについて議論をしょ ら。炭素質粒子の表面のガス境膜の厚さは流体力学的 に決定される。矢木, 国井 ${ }^{20)}$ は Hottel ら ${ }^{15)}$ の炭素 質粒子の燃燒速度式を採用し, 粒子と外部流体間の酸 素の拡散については Rantz-Marshall の式を用いて図 9 に示した計算を行なった。粒子レイノルズ数（ひい ては粒径と流速とが）がどのように炭素質粒子の燃燒 速度に影響するかが示されている。図 9 の左下方の曲 線はより低温の領域の補足のため著者が文献值より計 算して追補したものであることをお断わりする。

普通，炭素質燃焼の理論式の誘導に際し，炭素質の 温度は周囲ガス温度に等しいとされてきたが，小林92 は熱移動が Rantz-Marshall 式にしたがうという立場 で発熱反応による熱の移動を考慮して式を導いた結果 粒子温度キ周囲ガス温度

なることを指摘した。著者らも理論的および実験的 にこの事実を確認している。

しかし，実際上は同一ガス温度の空気中で，ある分 布をもつた炭素質粒子が燃焼している場合，粒子径に より粒子温度が異なるとすることは理論的取扱いを困 難にするので，等温系として議論をすることは工学的 にいつて止むをえないことであろう。

Essenhigh ${ }^{14}$ ほ 粒径 $100 \mu$ 以下の微小炭素質粒子の 燃燒においては，炭素質の立体因子，配向因子などに よつて, その燃焼速度は実際には計算值の $1 / 150$ の程 度の少ない值を示すことを指摘している。

\section{6. 重油噴霧燃焼にさいし排出される 残留炭素粒子の粒度分布と平均粒径}

前述のごとく, 重油噴霧燃焼を比較的高い温度の燃 燒室内で，粗くない微粒化状態でおこなう場合，排出 炭素質は残留炭素粒子がほとんどであるとしてよい。

このような炭素質の排出を抑制することを目的とし た工業技術上の問題として, 燃焼室の設計, 噴霧装置 の設計, 燃焼装置運転における操作条件, 使用すべき 重油の性質などと排出残留炭素粒子の粒度分布, 量, 平均粒径などとの関連が明らかにされなくてはならな い。

筆者らはさきに残留炭素粒子の粒度分布と平均粒径 についての工学的な 解明を 試みたので以下に 紹介す $ろ^{25)}$ 。

6-1 残留炭素粒子の 粒度分布と平均粒経について の理論式の誘導

噴霧燃焼は複雑な反応系であるが，解析するために

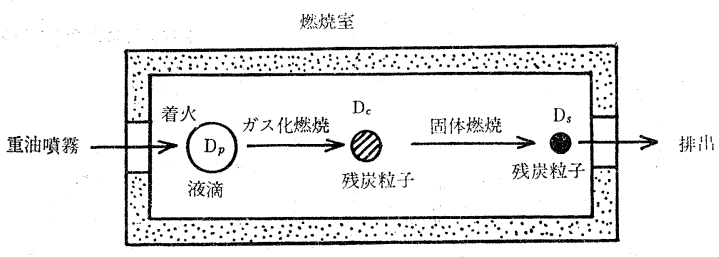

図 10 重油液滴の燃焼経過モデル

個々の重油滴は残留炭素粒子となり，燃えつきずに排 出される残留炭素粒子は図10のごときモデルで発生す るものと考え，スートは燃焼室内で然えつきるものと 考える。簡単のためにつぎの仮定をおく。

i ) 液滴群は燃焼室に入ると 同時一せいに 着火す る。

ii）燃燒室内は乱流で 押し 出し 流れとして 取扱え る。

iii）燃焼室内ではガス温度は一様。

iv ）液滴の蒸発燃燒にひきつづいて直ちに固体燃焼 に入る。

v）全過程を通じて粒子の合併分裂はない。 1 個の液滴がたどる燃焼過程を考えると，その燃焼室 内滞留時間は

$$
\theta=\theta_{\imath}+\theta_{s}
$$

液滴粒子の蒸発・気化燃焼による寿命は自乘則にした がらとして

$$
D_{p}^{2}=k_{l} \theta_{l}
$$

残留炭素粒子の粒径変化も自乗則にしたがらとして

$$
D_{c}^{2}-D_{s}^{2}=k_{s} \theta_{s}
$$

液滴 $\rightarrow$ 残留炭素粒子の過程における物質収支は

$$
D_{p}^{3} \rho_{l}\left(R_{c} / 100\right)=D_{c}^{3} \rho_{c}
$$

あるいは $\frac{D_{c}}{D_{p}}=\left(\frac{R_{c}}{100} \cdot \frac{\rho_{l}}{\rho_{c}}\right)^{1 / 3}=a$

（5）式によつて粒径炭化率 $\alpha$ が定義される。いま， (1), (2), (3) 式より

$$
\theta==\frac{D_{p}^{2}}{k_{l}}+\frac{D_{c}^{2}-D_{s}^{2}}{k_{s}}
$$

(5)，(6) 式より $D_{c}$ を消去して

$$
D_{p}=K\left(D_{s}^{2}+k_{s} \theta\right)^{1 / 2}
$$

ただし $K=\left(\frac{k_{l}}{k_{s}+\alpha^{2} k_{l}}\right)^{1 / 2}$

すなわち 液滴初期径 $D_{p}$ と残留炭素 (未着火) 粒径 $D_{c}$ との関係は双曲線となる。これを図示すれば図 11 のよらになる。双曲線が $D_{p}$ 軸と交わる点より以下の 粒径の重油滴から発生した残留炭素粒子は燃えつき, それ以上では残留炭素粒子として排出する。すなわち 


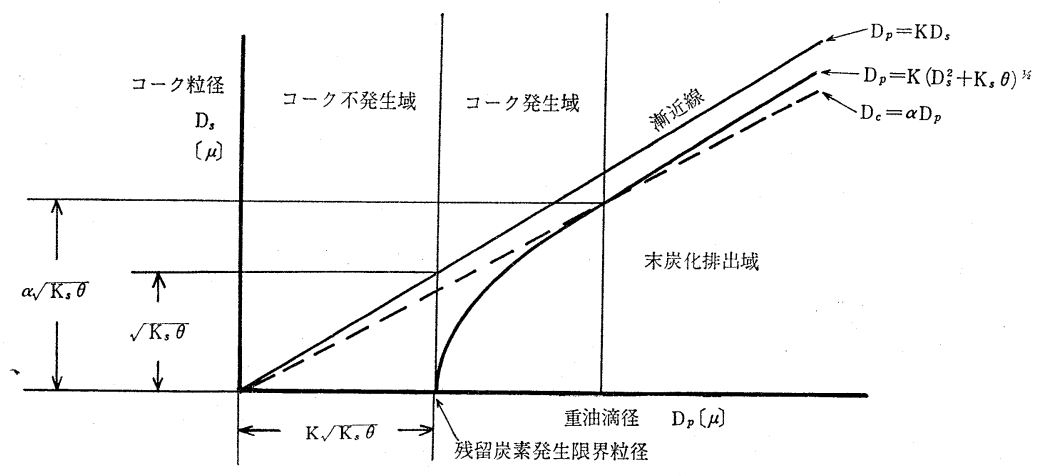

図 11 炭素質が拡散律速で燃焼する場合の $D_{p}-D_{s}$ の関係

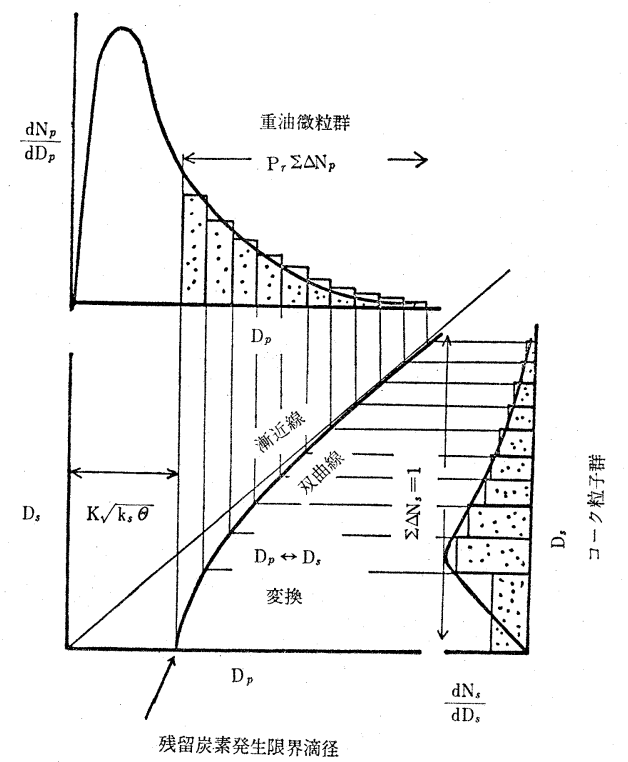

図 12 重油噴霧燃焼により生成するコーク 粒子の粒度分布回式解法

この点は残留炭素排出限界液滴径で, 残留炭秦粒子排 出の条件は

$$
D_{p}>K \sqrt{k_{s} \theta}
$$

となる。

以上は個々の粒子に注目して議論したが，つぎに， 液滴群について考える。重油液滴群の個数粒度分布は
抜山，棚沢の ${ }^{2622728)}$ 提案によるガンマ分布関数がよく 適合するのでこれを採用する。すなわち

$$
\frac{d N_{p}}{d D_{p}}=a D_{p}^{2} e^{-b D_{p}^{n}}
$$

ここで $a$ は規格化のための係数で

$$
a=\frac{n b^{3 / n}}{\Gamma(3 / n)}
$$

(7) 式を $D_{s}$ につき微分して

$$
\frac{d D_{p}}{d D_{s}}=K D_{s}\left(D_{s}^{2}+k_{s} \theta\right)^{-1 / 2}
$$

残留炭素粒子の粒度分布は未規格のとき

$$
\begin{aligned}
\frac{d N_{s}^{*}}{d D_{s}}= & \left(\frac{d N_{p}}{d D_{p}}\right)\left(\frac{d D_{p}}{d D_{s}}\right) \\
= & a K^{3}\left(D_{s}^{2}+k_{s} \theta\right)^{1 / 2} D_{s} \\
& \exp \left\{-b K^{n}\left(D_{s}^{2}+k_{s} \theta\right)^{n / 2}\right\}
\end{aligned}
$$

いま $P r$ を $\int d N p=1$ なる液滴群 から $N_{2}^{*}$ 個の残留 炭素粒子がえられる割合とすると規格化された残留炭 素粒子群の粒度分布は

$$
\begin{aligned}
\frac{d N_{s}}{d D_{s}}= & \frac{a}{p_{r}} K^{3}\left(D_{s}^{2}+k_{s} \theta\right)^{1 / 2} D_{s} \\
& \exp \left\{-b K^{n}\left(D_{s}^{2}+k_{s} \theta\right)^{n / 2}\right\}
\end{aligned}
$$

このようにして, 残留炭素粒子の 粒度分布がえられ た。（14）式の粒度分布をもつ残留炭素粒群の平均粒 径は

$$
D_{s p q}^{p_{-} q}=\frac{\int_{0}^{\infty} D_{s}^{p+1}\left(D_{s}^{2}+k_{s} \theta\right)^{1 / 2} \exp \left\{-b K^{n}\left(D_{s}^{2}+k_{s} \theta\right)^{n / 2}\right\} d D_{s}}{\int_{0}^{\infty} D_{s}^{q+1}\left(D_{s}^{2}+k_{s} \theta\right)^{1 / 2} \exp \left\{-b K^{n}\left(D_{s}^{2}+k_{s} \theta\right)^{n / 2}\right\} d D_{s}}
$$

であたえられることになる。

(14) 式は計算にさいし煩雑である。図 12 に図式
解法を示した。図 12 は（10）式と（14）式との関係 を表わしている。 
6-2 実験炉における重油燃焼実験

図13，14，15に示した実験炉と捕集装置を用いて, 粒度分布既知の重油噴霧から生成される残留炭素粒子 群の粒度分布と平均粒径とを求めた。重油噴霧を捕集 して粒度分布を調べるために捕集液にエチルセルロー

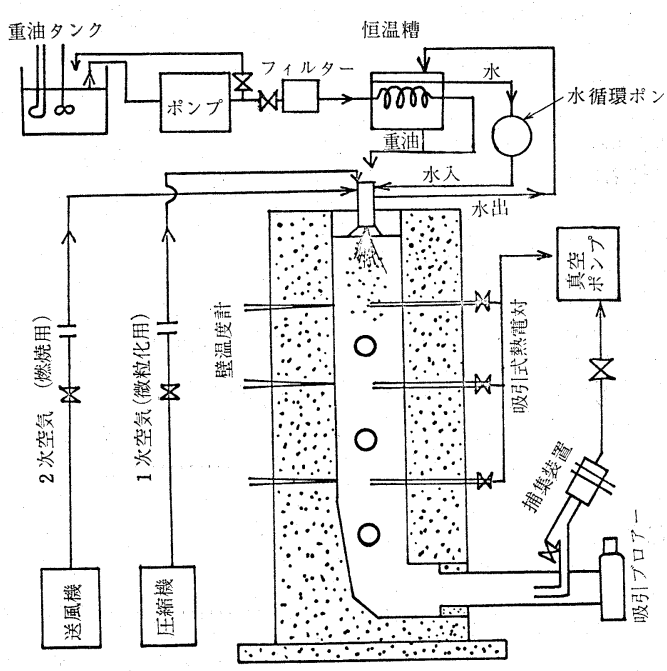

図 13 実験炉のフローシート

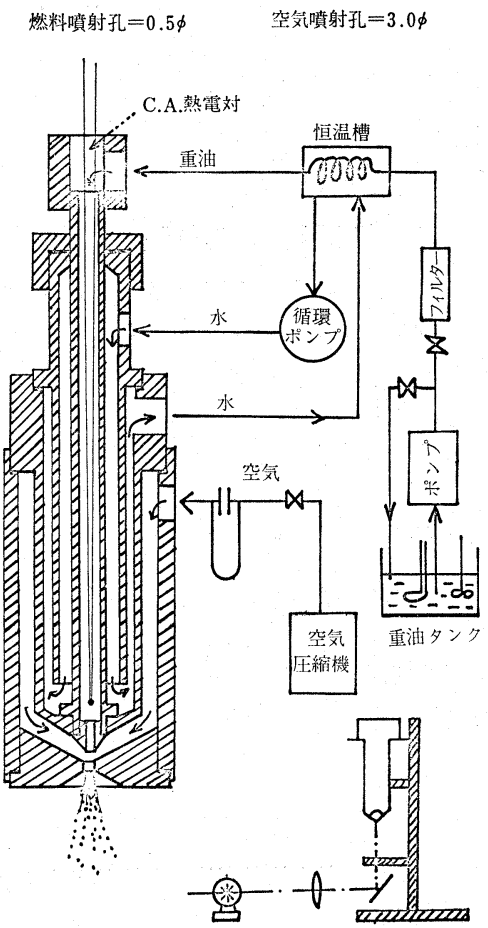

図 14 重油微粒化ノズルと微粒化装置およ び粒度分布の測定装置

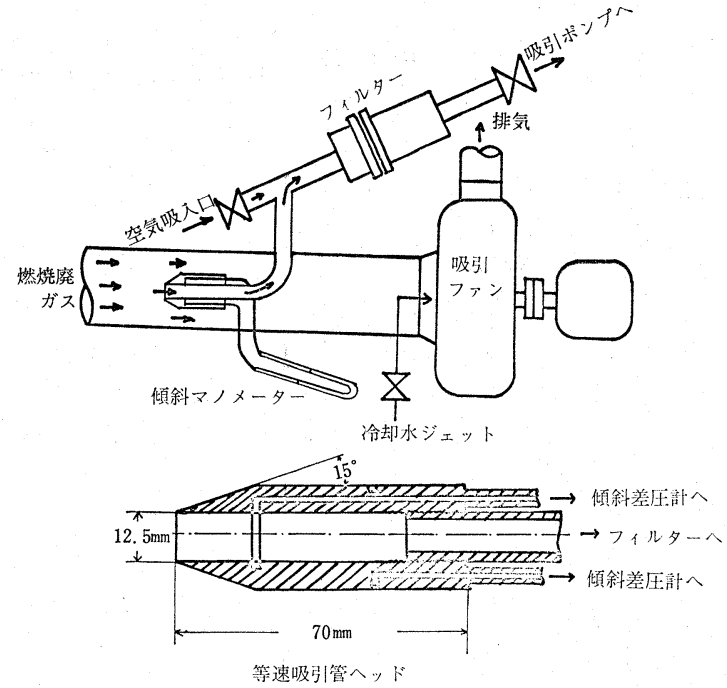

図 15 炭素質粒子の捕集装置

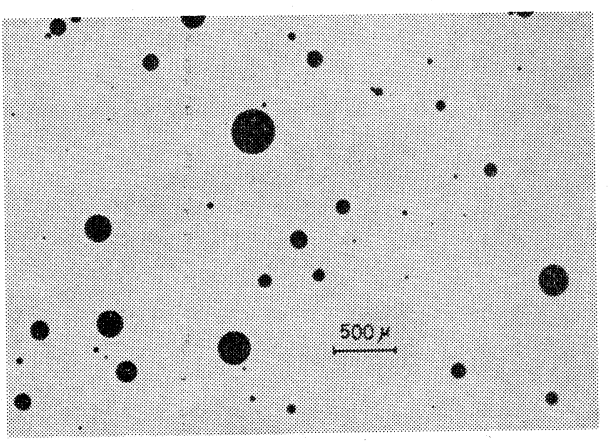

重油流量 $=90 \mathrm{cc} / \mathrm{min}$, 相対速度 $70 \mathrm{sec}$

図 16 B 重油噴霧の粒度写真例

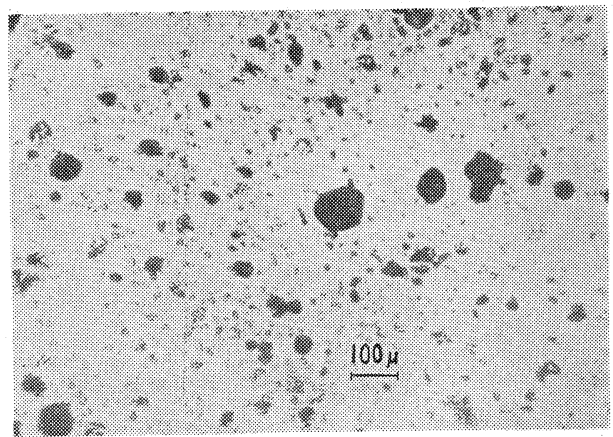

B 重油流量 $50 \mathrm{cc} / \mathrm{min}$, 相対速度 $50 \mathrm{~m} / \mathrm{sec}$ 空気率 $=1.20$, 炉温約 $1,000^{\circ} \mathrm{C}$

図 17 実験炉における捕集炭素質粒子

ズのエチルアルコール溶液を, 残留炭素粒子の捕集は ナイロンろ紙を用い，ろ紙はタクレゾールで溶解 


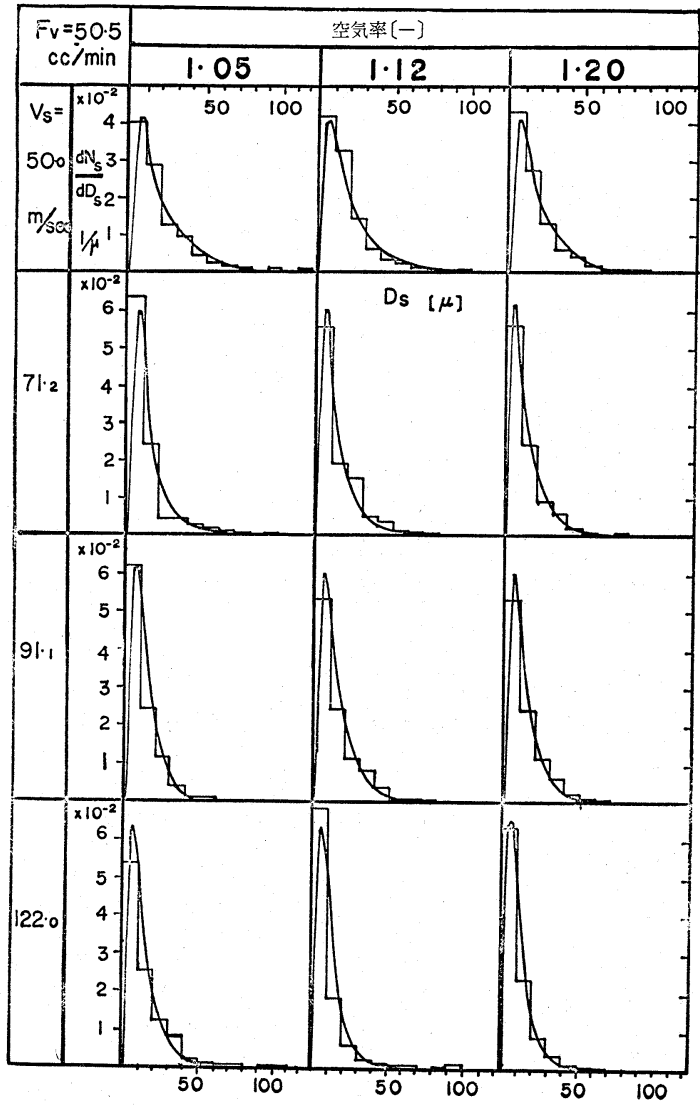

図 18 コーク粒度分布の計算曲線と実測 ヒストグラムの比較

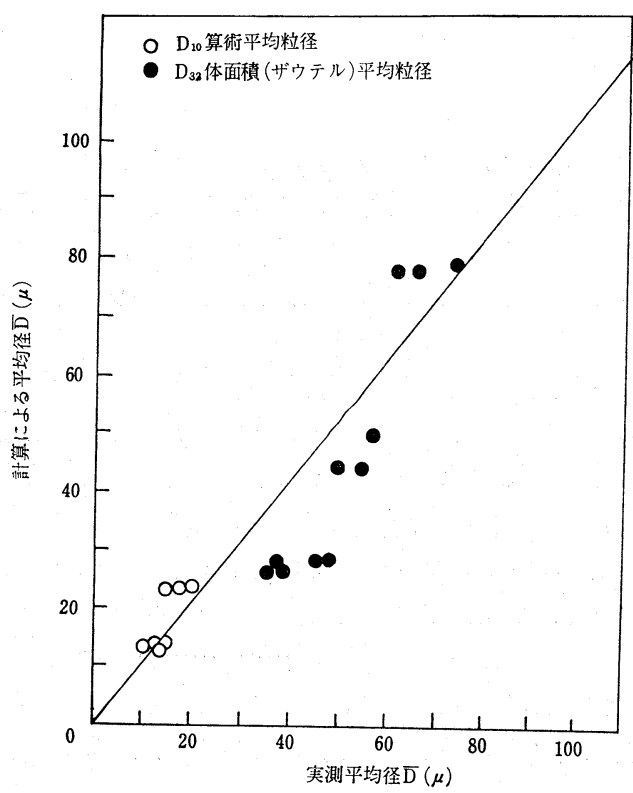

図 19 平均粒径の計算値と実測値との比較

し，粒子の測定は写真法によつた。図16に重油噴霧滴 を捕集板上に捕集した例を，図17に残留炭素粒子の写 真をそれぞれ示した。

結果を表 3 および図18，19に示した。理論式によつ て計算した残留炭素粒子の粒度分布と実験によつて得 たヒストグラムとはよい一致を示し，平均粒径もまず 一致しているといえよう。計算は電子計算機を使用し

表 3 微粒化重油滴とその燃焼によつて生成した炭素質粒子の実験および計算值

然焼条件

重 油噴霧 群

炭素質 粒 群

\section{微粒化条件 分布の係数平均粒径}

空気率 炎温度 $\overbrace{F_{v} \quad V_{s}} \overbrace{n \quad b} \overbrace{\bar{D}_{p_{10}} \bar{D}_{p_{32}}}$

\section{[-]}

$\left[{ }^{\circ} \mathrm{C}\right][\mathrm{cc}$ $\left[\begin{array}{ll}{[\mathrm{cc}} & {[\mathrm{m}}\end{array}\right.$

$\begin{array}{lll}1.049 & 1200 \quad 50.0\end{array}$ $[\mathrm{m}$

[-]

1. $124 \quad 1200 \quad 50.0$

$\begin{array}{lll}50.0 & 0.330 & 2.67\end{array}$

$\begin{array}{lll}50.0 & 0.330 & 2.67\end{array}$

$50.0 \quad 0.330$

2.67

$\begin{array}{ll}71.2 & 0.390\end{array}$

2.16

$\begin{array}{ll}71.2 & 0.390\end{array}$

2.16

$71.2 \quad 0.390$

2.1632 .2

$[\mu]$

$[\mu]$

$\begin{array}{lllll}53.4 & 226.9 & 21.6 & 73.2 & 0.324\end{array}$

$\begin{array}{lllll}53.4 & 226.9 & 21.6 & 73.2 & 0.324\end{array}$

$\begin{array}{lllll}53.4 & 226.9 & 21.5 & 73.1 & 0.323\end{array}$

$\begin{array}{lll}32.2 & 108.2 & 13.2\end{array}$

$\begin{array}{ll}41.8 & 0.387\end{array}$

1. $124 \quad 1200 \quad 50.0$

$\begin{array}{lll}1.199 & 1200 & 50.0\end{array}$

$91.07 \quad 0.645$

0.5233 .1

108.2

$\begin{array}{lll}13.1 & 41.8 & 0.387\end{array}$

$\begin{array}{lll}13.1 & 41.7 & 0.386\end{array}$

1. $124 \quad 1300,50.0$

$91.07 \quad 0.645$

$0.52 \quad 33.1$

108.2

$\begin{array}{lll}12.3 & 26.3 & 0.367\end{array}$

$\begin{array}{llll}71.4 & 12.3 & 26.3 & 0.367\end{array}$

(1)

1.0491300

$\begin{array}{rrrr}50.0 & 91.07 & 0.645\end{array}$

$\begin{array}{ll}0.53 & 30.7\end{array}$

1. 1241300

$\begin{array}{llll}50.0 & 121.97 & 0.650\end{array}$

$\begin{array}{ll}0.53 & 30.7\end{array}$

1.1991300

$\begin{array}{lll}50.0 & 121.97 & 0.650\end{array}$

$0.53 \quad 30.7$

$\begin{array}{llll}65.7 & 11.5 & 24.4 & 0.371\end{array}$

$\begin{array}{llll}65.7 & 11.5 & 24.4 & 0.371\end{array}$

$\begin{array}{llll}65.7 & 11.5 & 24.4 & 0.371\end{array}$

$\alpha=0.386[-], \quad k_{l}=2.0 \times 10^{6}\left[\mu^{2} / \mathrm{sec}\right], k_{s}=5\left[\mu^{2} / \mathrm{sec}\right]$ 
た。図18と表 3 をみると, 残留炭素粒子の粒度分布に たいし空気率は大きな影響は認められず，その分布は ほとんど最初の重油噴霧の粒度分布によつて定まる。

このように，重油の噴霧燃焼に際して発生する残留 炭素粒子の粒度分布や平均粒径は, 重油噴霧の粒度分 布にいちじるしく左右される。したがつて，重油の良 好な燃焼をうる目的からみて，微粒化といら操作が非 常に大切であることが指摘される。

6-3 残留炭素粒子が化学反応律速で然焼する場合 比較的低温 (500 $800^{\circ} \mathrm{C}$ 程度) の燃焼温度で重油 噴霧燃焼が行なわれる場合には低温化学反応律速とし て分布式を導かなくてはならない。この場合, $D_{p}-D_{s}$ の関係はつぎのようになる。まず, 残留炭素粒子の燃 焼は化学反応律速だから粒径の 1 次式になり

$$
D_{c}-D_{s}=k_{s}^{\prime} \theta_{s}
$$

ここで $k_{s}^{\prime}$ は化学反応律速の燃焼速度 $[\mathrm{mm} / \mathrm{sec}]$ である。(1)，(2)，(16）および（5）式より

$$
D_{s}=\frac{k_{s}^{\prime}}{k_{l}} D_{p}^{2}+\alpha D_{p}-k_{s}^{\prime} \theta
$$

が得られ， $D_{p}-D_{s}$ の関係は化学反応律速では 2 次式 (放物線) になる。(17) 式より残留炭素粒子の粒度分 布式の誘導は煩雑であるので, この場合には図13に示 した図式解法を用いれば容易に分布が求められる。 (17）式の関係は図示すれば図20のごとくなり, 残留 炭素粒子発生の限界液滴径は (17) 式で $D_{s}=0$ とお いて 2 次式をとけぼ

$$
D_{p}>\frac{-\alpha+\left(\alpha^{2}+4 k_{s}^{\prime} \theta\right)^{1 / 2}}{2 k_{s}^{\prime} / k_{l}}
$$

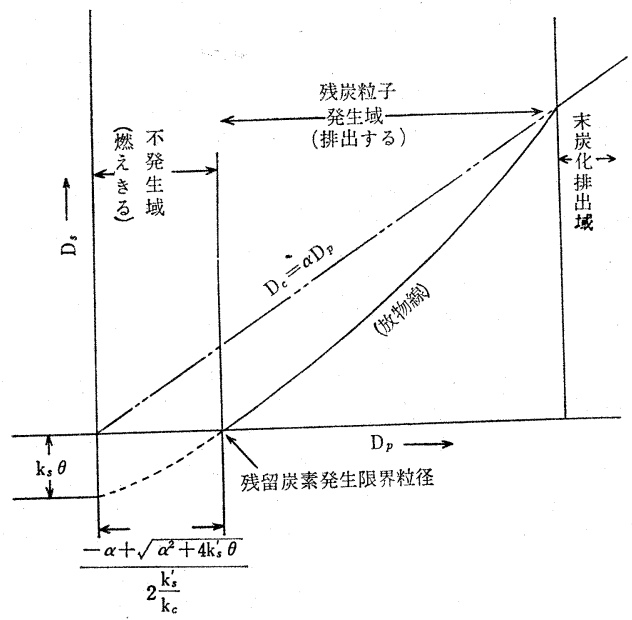

図 20 低温化学反応律速で炭素質が燃焼する場 合における重油滴径と殘留炭素径の闒係
の範囲で残留炭素粒子が排出されることになる。

\section{7. 式を応用する場合に留意すること}

$7-1 \quad k$ と $\alpha$ との関係

燃焼室内温度は普通 $1,000^{\circ} \mathrm{C}$ をこえることが多い ので，炭素質は拡散律速で然焼しているとしてよい。 (18) 式を変形して

$$
K=\left(\frac{1}{k_{s} / k_{l}+\alpha^{2}}\right)^{1 / 2}
$$

ここで，普通は $k_{l} \gg k_{s}$ であるから

$$
K=\frac{1}{\alpha}
$$

として計算して差支えない。

7-2 残留炭素粒子の最大粒径から 噴霧粒径の 推定 をすること

重油噴霧粒群中の最大粒径液滴が最大粒径をもつ残 留炭素粒子になるとしてよいから，（7）式はそのま ま

$$
D_{p \max }=K\left(D_{s \max }^{2}+k_{s} \theta\right)^{1 / 2}
$$

と書くことができる。

(21) 式により, 捕捉した残留炭素粒群の 最大粒径か ら重油噴霧群の最大粒径の推定ができる。この場合燃 焼室内は押し出し 流れの仮定に近いことが条件とな る。

各種のノズルにおいて, 体面積平均粒径と最大粒径 との関係が報告されている。表4にそれらを示した。 表 4 の值を用いれば $D_{p}$ max の值から体面積平均粒 径 $D_{p 32}$ を推算可能である。

表 4 各種ノズルにおける $D_{\max }$ と $\boldsymbol{D}_{32}$ の関係 ノズルの型式 $D_{\max }$ と $\bar{D}_{32}$ との関係 研究者 压力噴射弁 $D_{p \text { max }}=(2 \sim 2.5) \bar{D}_{32}$ 棚沢 渦巻噴射弁 $D_{p \max }=2.5 \bar{D}_{32}$ 2 流体ノズル $D_{p \max }=(1.8 \sim 3.0) \bar{D}_{32} \quad "$

"（重油） $D_{p \text { max }}=(2 \sim 2.5) \bar{D}_{32}$ 佐賀井, 山田 回転ノズル $D_{p \max }=(2 \sim 2.5) \bar{D}_{32}$ 倉林

\section{ま と め}

重油噴霧燃燒にさいして発生する炭素質の発生過程 とその外観およびX線による解析によつて判定するこ とができ, 重油噴霧燃焼によつて得られる炭素質はス 一ト (気相析出炭素質) とコーク (残留炭素) の 2 種 に大別されることがみとめられる。比較的細かい噴霧 を燃焼させると，スートは燃えつきて主として残留炭 素粒子が排出される。

抜山, 棚沢の提案したガンマ分布関数を重油液滴群 
に適用し，1個の重油滴から 1 個の残留炭素粒子が生 成されるとして，残留炭素粒子の粒度分布と平均粒径 とを理論的に導くことができる。この式による計算曲 線と実測ヒストグラムおよび計算平均径と実測平均径 とはよい一致を示している。

このような研究結果から，排出残留炭素粒子をなく すためつぎのようなことが考えられる。すなわち, 「重油噴霧の最大粒子から 発生した残留炭素粒子が燃 焼室内で完全に燃えつきること」である。

そのための条件として，炭素質の燃焼が $1,000^{\circ} \mathrm{C}$ 前 後で進行するときは,

$$
D_{p \max } \geqq K\left(k_{s} \theta\right)^{1 / 2}
$$

である。

以上からいえることは重油の噴霧燃焼にさいして発 生する炭素質を抑制のための対策としては，大まかに いって

(1) 最大液滴径を小にする：ノズルの改良や適当な 機器の選択, ノズルに対し適正な粘度の油の使用, 微 粒化操作法の改善, 添加剤の使用など。

(2) 同一最大液滴径の噴霧でより少ない残留炭素粒

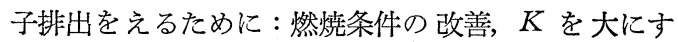
る。すなわち $\alpha$ の小なる油を選ぶ（残炭の少ない，あ るいは蒸発速度の速い軽質油)。 $k_{s}$ を大にする。すな わち, 酸素分圧を上げて 2 次燃焼の促進。炉温を上げ る。酸素の混合拡散をよくする。燃焼触媒の添加。

(3) 充分反応時間をとるため燃燒室を大にする, 燃 焼負荷を低くする，などが考えられる。

なお，粒度分布がガンマ分布関数にしたがう場合の 係数の決定方法については筆者らの報告 ${ }^{28)}$ を参照いた だきたい。

本稿に述べた筆者らの研究の多くは名古屋大学工学 部杉山幸男教授にご指導いただいた。記して深く御礼 申し上げます。

$$
\text { 〔記号〕 }
$$

$\begin{array}{rll}b: & \text { ガンマ分布関数の係数 } & {\left[\mu^{-n}\right]} \\ D: & \text { 直径 } & {[\mu]} \\ F_{v}: & \text { 容積流量 } & {[\mathrm{cc} / \mathrm{min}]} \\ K: & \text { 倸数 } & {[-]} \\ k: & \text { 燃焼速度 } & {\left[\mathrm{mm}^{2} / \mathrm{sec}\right]} \\ n: & \text { ガンマ分布関数の係数 } & {[-]} \\ N^{*}: & \text { 個数 } & {[-]} \\ N: & \text { 規格化された個数 } & {[-]} \\ P_{r}: & \text { 粒数比 } & {[-]} \\ V_{s}: & \text { 相対速度 } V_{s}=V_{a}-V_{l} & {[\mathrm{~m} / \mathrm{sec}]} \\ \alpha: & \text { 粒径炭化率 } & {[-]}\end{array}$

$$
\begin{array}{cl}
\rho: & \text { 比重 } \\
\theta: & \text { 時間 } \\
\text { 添字 } & \\
c: & \text { コーク } \\
l: & \text { 液体 } \\
p: & \text { 液滴 } \\
s: & \text { 固体 }
\end{array}
$$$$
[\mathrm{g} / \mathrm{cc}]
$$

\section{文献}

1）佐賀井，杉山，工化誌， 68，4，736 (1965)

2) 大谷，日機誌，67，541，245 (1964)

3) Thomas, A., Combustion and Flame, 6, 1, 46 (1962)

4) 秋田, 燃燒研究, 3 号, 10, (1961)

5) 野田, 特殊䆛業品 (工業化学全書) p 149 日刊工 業新聞社 (1962)

6) Sinnatt F. S.: J. Soc. Chem. Ind. Trans., Jun., 1 (1928)

7) Godsave G. A. E., N. G. T. E. Rep., R-125

8) Hottel H. C. et al., 5 th symp. on combustion (1955)

9）小林, 機械の研究, 10, 7 (1958); ibid., 10, 11 (1958)

10) Masidin E. G. and P. J. Foster, Fuel, 39, 413 (1960)

11) Topps J. E. C., J. Inst. Fuel, 37, 535 (1951)

12）佐賀井，山田，石油誌，6，12，925 (1963)

13) Otani, Hinohara and Sakai, Carbon, 1, 215 (1964)

14) Essenhigh R. H., J. Inst. Fuel, 34, 245, 239 (1961); I. E. C., 57, 9, 33 (1965)

15) Hottel and Parker, I. E. C., 28, 1334 (1936) Hottel, Davis and Tu, ibid., 26, 749 (1934)

16) Nusselt. W., Ver. Deutsh. Ing., 68, 124 (1924)

17) Burke and Schumann, I.E.C., 20, 998, (1928)

18) 功刀, 神野, 化学工学, 25, 1, 84 (1961)

19) Spalding D. B., Some fundamental on combustion (1955)

20) 矢木, 国井, 5 th Symposium on Combustion (1955)

21）佐賀井，日野原，下川，石油誌，5，2，89（1962）

22) Wicke E., 5 th Symposium on Combustion (1955)

23）小泉, 日機論 ( 2 部)，26，165，754 (1960)

24）佐賀井, 鬼頭, 石丸, 川原, 杉山, 第 6 回燃燒シ ンポジウム前刷 (1968) 
25）佐賀井，杉山，化学工学，31，9，90 (1967)

26）佐賀井，山田，工化誌，65，11，1761 (1962)

27) 佐賀井, 杉山, 化学工学, 29, 1, 14 (1965)
28）拔山，棚沢，日機論， 5, 18，131 (1939)

29) 横井, 伊藤, 磯貝ら, 熱機関体系 7 ・ディーゼル 機関 II, p 131 および p 212 (1956) 山海堂版

\title{
Formation of Carbonaceous Products During the Combustion of Heavy Fuel Oil Droplets
}

\author{
by Takeshi Sakai
}

\section{(Gunma Univ.)}

SYNOPSIS : - The carbonaceous products generated during the combustion of heavy fuel oil spray can be classified into two groups. One of them is the carbonaceous product so called "soot" which is deposited from gasphase and the other is the residual carbon so called "coke" from liquidphase. The generative processes of the two types are discussed.

Through some considerations of single droplet combustion, the coke generative droplet diameter can be written as the following equation.

$$
D_{p \text { crit }}=K_{\sqrt{k_{s} \theta}}
$$

If the maximum diameter of the heavy fuel oil droplets is smaller than the value of $K \sqrt{k_{s} \theta}$ all residual carbon particles and soot particles should be burnt out completely. The relations between the distribution and mean diameters of the atomized heavy fuel oil droplets and the residual carbon particles are discussed. 